\title{
RESEARCH ON THE USE OF ECO-DRIVING IN CITY TRAFFIC
}

Jacek Caban ${ }^{1, *}$

\begin{abstract}
As it is commonly known, during the operation of vehicles, their operational parameters change, related to the influence of working factors, the current road situation or wear processes of vehicle components. Currently, for many years there has been a discussion on improving the environmental properties of motor vehicles, considering technical, legal and operational factors. The article presents selected research results of a vehicle using the eco-driving technique in city traffic on the so-called routine route in a selected area of the city of Lublin in south-eastern Poland. The tests were carried out on a passenger car with a spark ignition engine powered by gasoline. The obtained test results focus on the influence of selected driving parameters, such as: average speed, driving time, mileage, road characteristics, number of stops, number of brakes. The conducted research indicates the possibility of using eco-driving in city traffic and gives positive results.
\end{abstract}

Keywords driving style, ecology, maintenance, road transport, technical system, travel time

\section{INTRODUCTION}

The transport situation in many cities around the world is deteriorating due to the increase in the number of vehicles and the limited capacity of the existing road infrastructure. The transport sector is influenced by a wide range of external social and economic factors such as demographics, living standards of the population, urban planning, organization of production, structural changes in society and accessibility to transport infrastructure Veternik and Gogola, (2017). The road network of each city consists of various types of intersections, which enable the handling of collision traffic flows and which can be bottlenecks of the transport system Macioszek and Kurek, (2019). Because of the narrow streets and density of existing buildings within the city, in most cases it is not possible to extend current infrastructure Kalasova et al., (2014). The traffic intensity in a given city is not distributed equally throughout the day and over the entire area Salisu and Oyesiku, (2020). For these reasons, problems arise in an urban agglomeration related to the phenomenon of transport congestion. This phenomenon is a very complex process, widely described in the literature (Cernicky and Kalasova, 2015; Hurtova et al., 2018; Kalasova et al., 2020; Kurganov et al., 2020; Lizbetin and Bartuska, 2017). It is also connected with the pollution of the natural environment in the city caused by means of transport. The emission of air pollutants has a negative impact both on the environment and human health as well as on climate change (Haider et al., 2017; Konećny et al., 2020, Piekarski et al., 2016; Uhereketal et al., 2010). Nocera and Cavallaro, (2011) demonstrated that the emissions from transport comprise $26 \%$ of the total $\mathrm{CO}_{2}$ emissions in the $\mathrm{EU}$ and in this zone are a major factor in air pollution worldwide. In turn, Caulfield et al. (2014) showed that it is possible to reduce exhaust

\footnotetext{
${ }^{1}$ Lublin University of Technology, Faculty of Mechanical Engineering, Department of Automation, Nadbystrzycka 36, 20-618 Lublin, Poland.

Corresponding author: e-mail: j.caban@pollub.pl
} 
gas emissions by using the on-board feedback tool for eco-driving. More details on the idea and technique of eco-driving, its benefits and challenges for improving road traffic are presented by Alam and McNabola, (2014) and Caban et al., (2019).

Traffic accidents are another equally important threat from road transport. They have great consequences for individual road users, have a social and financial impact on the families of accident victims, and more broadly on the economy, etc. Szumska et al., (2020) demonstrated that almost 3,700 people are killed daily all over the world in road traffic accidents involving pedestrian or different transport mode such as vehicles, buses, motorcycles, bicycles, trucks. In the literature we can find many publications in which the authors research impact of the traffic safety (Backalic et al., 2019; Hudak and Madlenak, 2016; Szymanek, 2020; Vrabel et al., 2020), of vehicle technical condition (Borawski et al., 2020; Orynycz et al., 2020; Rymarz et al., 2016) and effective driving (Cernicky and Kalasova, 2015; Skrucany et al., 2017; Tarkowski and Rybicka, 2020).

It should be remembered that a human, among of all transportation system elements has the greatest adaptability to changing conditions and current requirements in road traffic. Therefore, the behavior of his vehicle on the road depends on the decisions made by the driver and it forces interaction of other road users. One of such decisions by driver is the self-improvement of the driving technique due to the economic, ecological and operational benefits of the vehicle defined by the term eco-driving. Many researchers see the potential in eco-driving, to improve the traffic safety (Ho et al., 2015; Rouzikhah et al. 2013), and economic factors in the form of reduced fuel consumption (Sivak and Schoettle, 2012; Suzdaleva and Nagy, 2014; Sarkan et al., 2018; Skrucany et al., 2017), as well as slower degradation of other vehicle components such as the braking system (Borawski et al., 2020; Ondrus et al., 2018; Pancik et al., 2020), suspension (Blatnicky et al., 2020) or tires (Waluś and Warszczyński, 2019). Eco-driving is also responsible for analysing the situation on the road, anticipating the manoeuvres of other road users and skilful braking with the vehicle. Braking is a dynamic effect, when changing the speed of the vehicle at the time and at a certain route (Ondrus et al., 2018; Skrucany et al., 2020a). In addition, fuel consumption also depends on the driving style, as reported by Larson and Ericsson, (2009), Sarkan et al., (2018), Sivak and Schoettle, (2012), Synak et al., (2018).

Selected results of test of a vehicle in the eco-driving operation in urban road traffic area are presented. The aim of the study is to present the benefits of using the eco-driving style in urban traffic on a fixed route. The results of the influence of the eco-driving style according to the recommendations presented in the earlier study by the author Caban et al. (2019), on selected parameters, such as: average speed, driving time, road type, number of stops and the number of brakes, were compared to the normal driving style. The driving tests were carried out with a passenger car powered by a gasoline combustion engine in urban traffic conditions, move in the so-called "routine route": work-home on a selected city area.

\section{METHODOLOGY}

The research were carried out in the city of Lublin at the same specified time of day (afternoon peak traffic) and under comparable traffic conditions, on the same road section - driving from work to home "routine route". During the tests, a driver's behaviour and various operational activities performed (e.g.: accelerating, braking, stopping the vehicle, etc.) were recorded. The values of individual parameters were manually recorded by the driver in the previously prepared measurement protocol. In order to demonstrate the obtained benefits of eco-driving, the results collected in road tests were analysed and compared them to normal conditions, i.e. those that accompany traveling without economic driving habits.

The following parameters were considered in the research:

- number of vehicle braking,

- number of vehicles stops up to $0 \mathrm{~km} / \mathrm{h}$,

- number of vehicle movements, 
- number of stops at traffic lights,

- number of stops at intersections,

- number of stops before pedestrian crossing,

- maximum vehicle speed $[\mathrm{km} / \mathrm{h}]$,

- average vehicle speed $[\mathrm{km} / \mathrm{h}]$,

- length of the route $[\mathrm{km}]$,

- travel time [min].

\subsection{Characteristics of the test vehicle}

The tests were carried out on a 5-door Daewoo Lanos passenger car powered by a 100HP 1.5 DOHC gasoline engine with power transmission via a 5-speed manual gearbox to the front axle. Production date of the car is 2000 , and the vehicle mileage at the start of the tests was $83,560 \mathrm{~km}$. The vehicle has a curb weight of $1020 \mathrm{~kg}$, while the vehicle's weight was around $1150 \mathrm{~kg}$ during the tests. In the Table 1 was presented the chosen technical parameters of the engine used in the tested vehicle.

Tab. 1 Chosen technical parameters of the vehicle engine 1.5 DOHC, E-TEC; source: Bujański (2000).

\begin{tabular}{llr}
\hline Parameter & \multicolumn{2}{c}{ Value } \\
\hline Number and arrangement of cylinders & & 4-cylinders in line \\
Work cycle & & $1-3-4-2$ \\
Displacement & {$\left[\mathrm{cm}^{3}\right]$} & 1,498 \\
Compression ratio & & 9.5 \\
Cylinder diameter & {$[\mathrm{mm}]$} & 76.50 \\
Piston stroke & {$[\mathrm{mm}]$} & 81.50 \\
Total power & {$[\mathrm{kW} / \mathrm{KM}]$} & $73 / 100$ \\
at rotational speed & {$[\mathrm{rpm}]$} & 5800 \\
Torque & $\mathrm{Nm}]$ & 131 \\
at rotational speed & {$[\mathrm{rpm}]$} & 3400 \\
Ignition advance angle (for idle speed) & {$\left[{ }^{\circ}\right]$} & 10 \\
Idle speed & {$[\mathrm{rpm}]$} & $850+50$ \\
Cooling system & & Forced circulation \\
Lubrication system & & Forced circulation \\
\hline
\end{tabular}

\subsection{Characteristics of the test route}

A routine route from the workplace to the home was selected for the research. The basic characteristics of this route are shown in Table 2. This road was marked on the map shown in Figure 1. Point $\mathrm{A}$ is a beginning of the route - workplace, point $\mathrm{F}$ is end of the route - home. The intermediate points (B and $\mathrm{E}$ ) are larger intersections where the direction of the route has changed. The route was mapped using the portal: (www.dojazd.org).

Tab. 2 Characteristics of the test route from workplace to home; source: own study

\begin{tabular}{|c|c|}
\hline Route parameters & To home \\
\hline The length of the travel route & $\begin{array}{lll}{[\mathrm{km}]} & 7.7\end{array}$ \\
\hline Number of intersections with traffic lights & 7 \\
\hline Number of all pedestrian crossings & 34 \\
\hline Number of intersections without traffic lights & 11 \\
\hline Number of intersections with railway lines & 1 \\
\hline
\end{tabular}




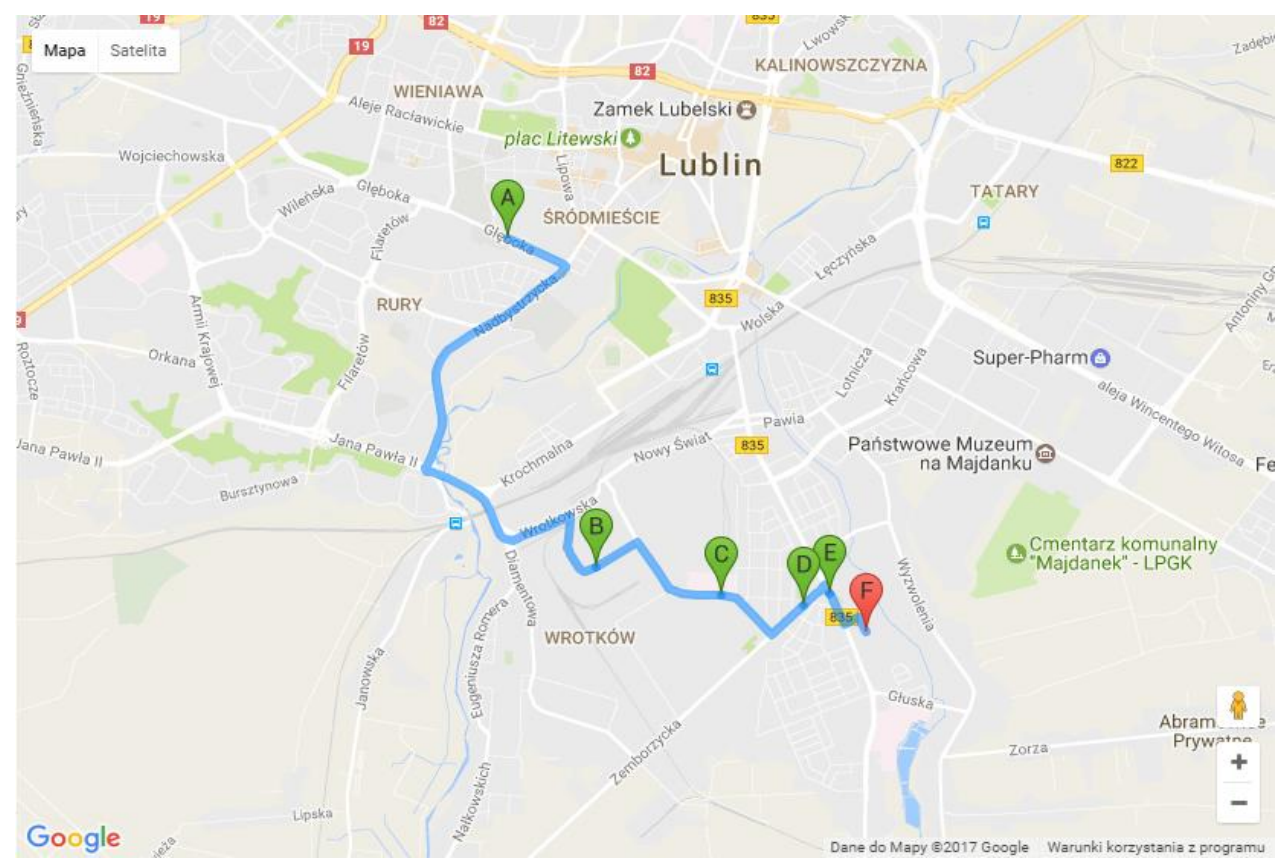

Fig. 1 Marked tested route from work - point A, to home - point F; source: (www.dojazd.org)

\section{RESULTS AND DISCUSSION}

This chapter presents selected results of road tests carried out on the test route from work to home. The focus is on the most important parameters that best illustrate the differences in driving style in an urban area. The presented test results concern the driving style in normal conditions and with the use of ecodriving technique, 28 tests were performed. Fig. 2 shows the results of tests on the number of brake applications, understood as the number of brake pedal depressions depending on the current road situation.

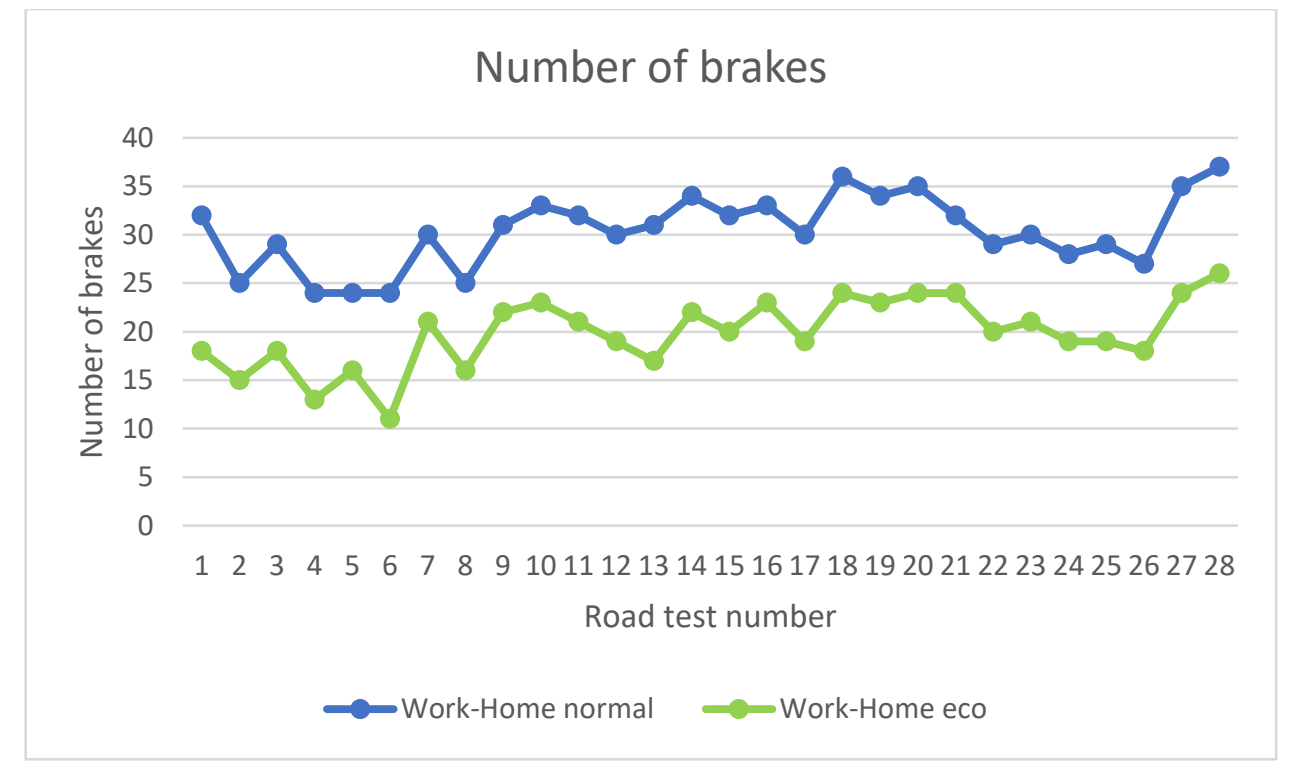

Fig. 2 The number of brakes applications depending on the driving style; source: own study

Analysing the data presented in Fig. 2, the values of the use of brakes in economic driving are much lower than in the normal driving style. In the case of the total number of brakes in the tests, a decrease by approx. $34.7 \%$ was recorded in the case of eco-driving. This state of affairs may be influenced by the fact that in the case of eco-driving, the driver observes the road situation better, which limits the excessive use of brakes and uses engine braking more often. In addition, the amount of acceleration of the vehicle 
approaching the intersection is limited, the driver, for example, anticipates the change of the traffic light on the signalling device, which reduces the amount of intense braking.

Fig. 3 shows the values of the total number of vehicle stops up to $0 \mathrm{~km} / \mathrm{h}$ depending on the used driving style.

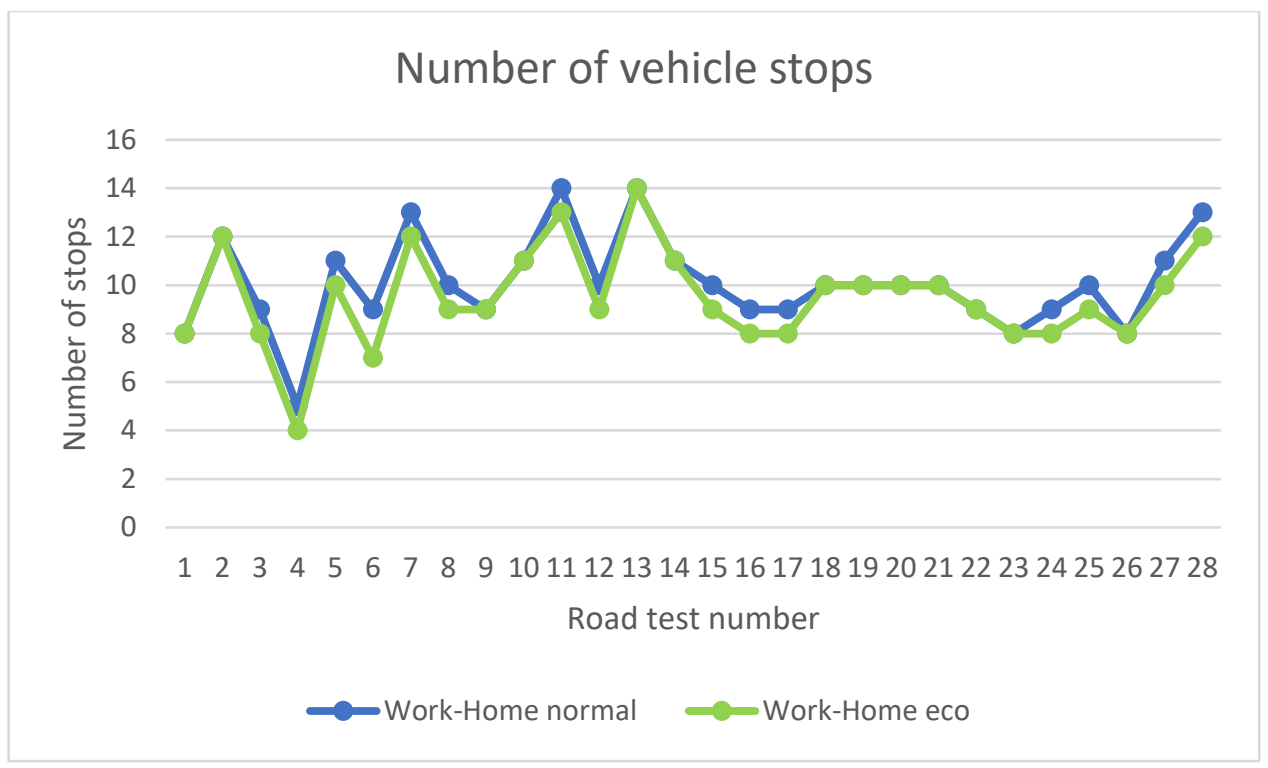

Fig. 3 The total number of vehicle stops up to $0 \mathrm{~km} / \mathrm{h}$; source: own study

Analysing the data presented in Fig. 3, it can be concluded that in most of the test drives the number of stops was lower than in the normal driving style. The total number of stops up to $0 \mathrm{~km} / \mathrm{h}$ takes into account e.g. traffic light stops, other intersections and, for stops before a pedestrian crossing. It can therefore be said, that when using the eco-driving technique, we maintain greater flow of traffic, which translates into a smaller number of vehicle stops when using this driving technique. Compared to aggressive driving, these differences may be even greater, but this type of behaviour has not been studied in this test.

Fig. 4 shows a comparison of the number of vehicle stops at intersections with traffic lights for both driving styles.

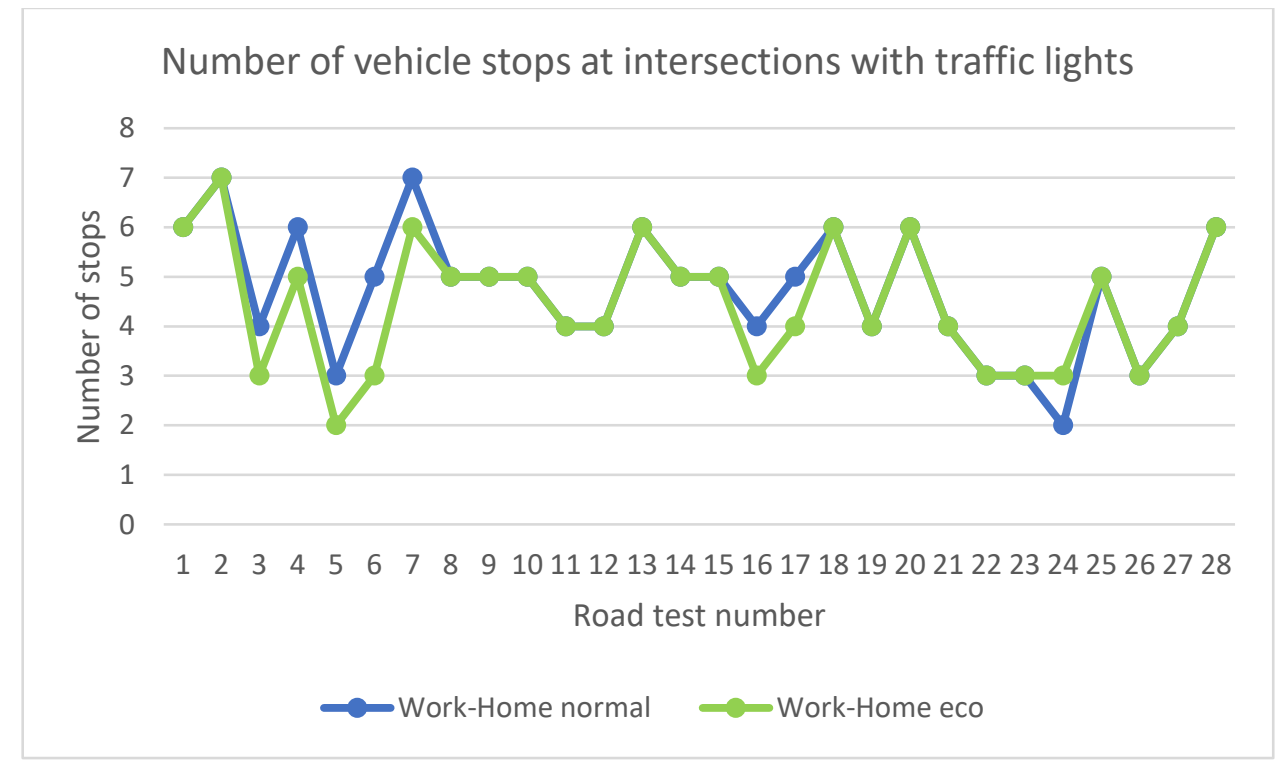

Fig. 4 The total number of vehicle stops at intersections with traffic lights; source: own study 
Analysing the data presented in Fig. 4, it can be concluded that in most test drives the number of stops was comparable for both driving styles. Smaller amounts of detentions occurred in 8 cases with eco-driving style. Which, as in the case analysed earlier, indicates better flow of traffic during eco-driving.

Fig. 5 shows the average speed values obtained in road tests for both driving styles.

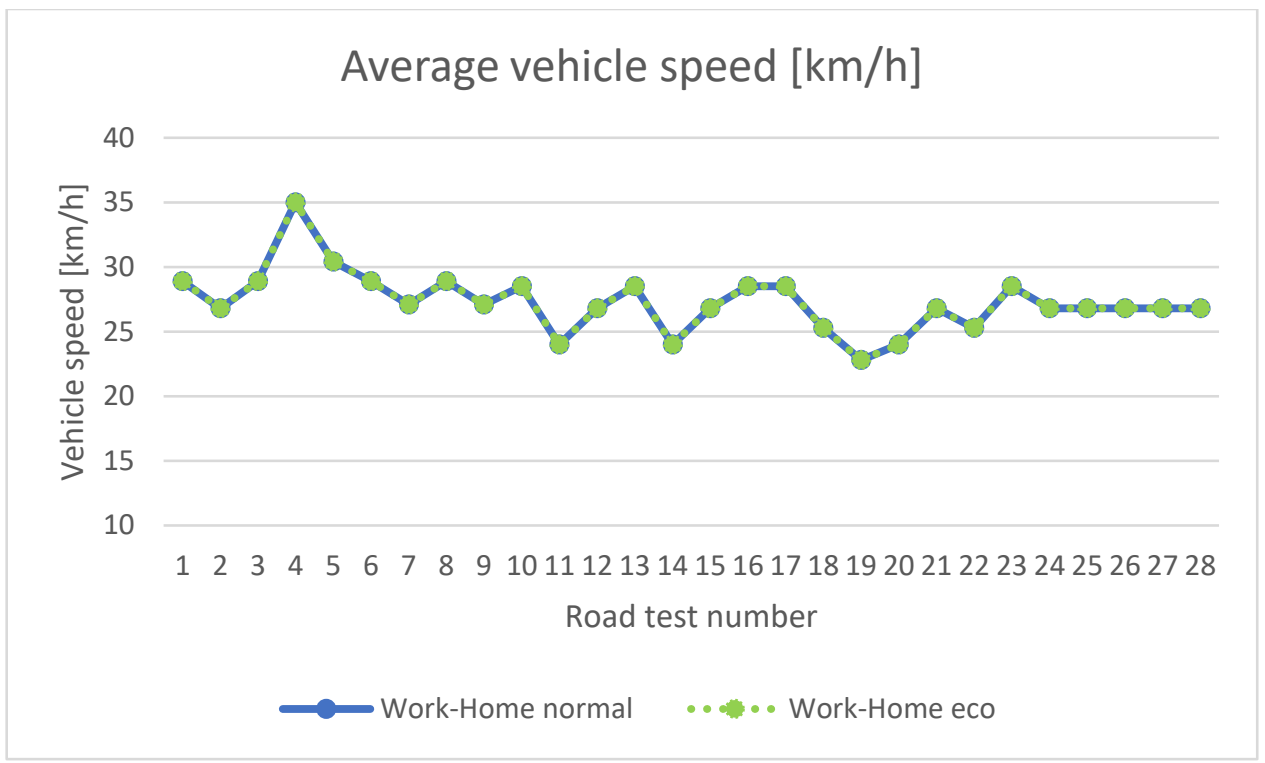

Fig. 5 The average vehicle speed values during road tests; source: own study

As shown in the data presented in Fig. 5, the average value of the vehicle speed on the tested road section was comparable for both driving styles, which proves that the driving style does not affect the average speed value. A similar tendency was observed in the case of the obtained travel time, which results is presented in Fig. 6. In the case of normal and eco-driving, the same values of travel time were obtained with an accuracy of one minute. Therefore, it can be concluded that changing the driving style to ecofriendly does not adversely affect the average value of the vehicle speed and travel time in urban traffic.

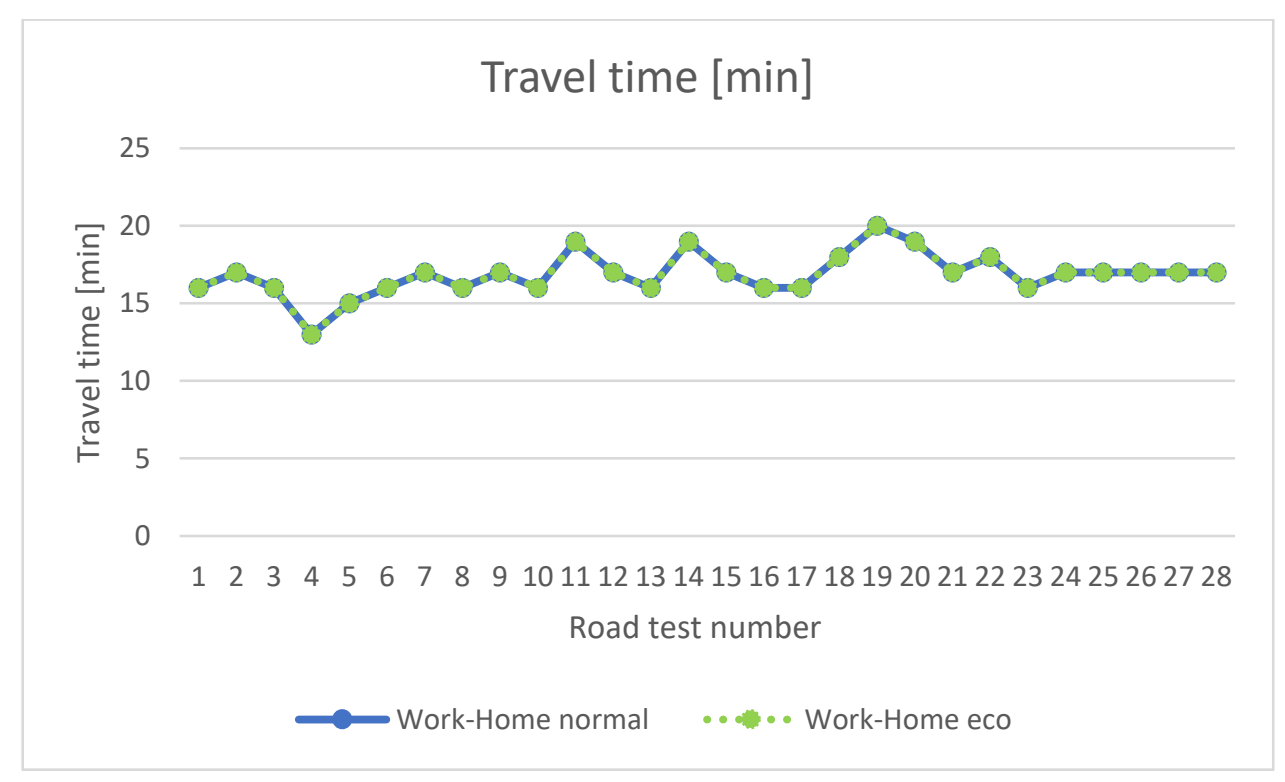

Fig. 6 The travel time values during road tests; source: own study

Based on the analysis of the results, it can be concluded that the lower number of braking has a positive effect on the emission of dust from the friction elements in the vehicle and extends the operation time of the brakes. Synak et al., (2018) demonstrated that the amount of fuel consumed may also be influenced by driving style. Based on the literature, it is known that eco-driving style have positive impact to reduces fuel consumption, which is signalised in the following works: Barkenbus, (2010), Mensing et al., (2014), 
Sivak and Schoettle, (2012), Skrucany et al., (2020). Sivak and Schoettle, (2012) demonstrated that an estimated for $45 \%$ reduction in fuel consumption in road traffic thanks to control of fallowing factors: aggressive driving, excessive engine speeds, route selection, engine settings, tire maintenance, air conditioning use, excessive idling, extra weight and incorrect engine oil. The influence of driving style on fuel consumption is noticeable in many reporting studies and fuel economy has also been achieved through the use of eco-driving habits: Sivak and Schoettle, (2012), Suzdaleva and Nagy, (2014), and Synak et al., (2018). It should be noted that the efficiency of a vehicle is not constant during its operation, but depends on the individual components of the driveline, which are related to vehicle speed and acceleration. Mensing et al., (2014) demonstrated that while the fuel consumption of a vehicle driven by eco-driving is achievable, the effect of reducing emissions of toxic compounds does not bring such obvious results. Barkenbus, (2010) demonstrated that eco-driving is a neglected climate change initiative and following the eco-driving policy may reduce fuel consumption by $10 \%$, which in turn will reduce emissions. Summing up, it should be stated that the consistent change of the driver's reaction, constant learning and the use of eco-driving habits contribute to the reduction of fuel consumption and pollution emissions.

Delhomme et al. (2013) demonstrated that young and average age drivers showed difficulties in adjusting to the style of economic driving, which may result from the reluctance of the respondents to learn and change their habits. Šeibokaitè et al., (2019) presented a naturalistic study of the behaviour of drivers on urban roads depending on the vehicle brand owned. The study showed that some drivers of a given vehicle make (BMW) display a more aggressive driving style than owners of other vehicle manufacturers (e.g. VW, Volvo). In urban traffic conditions it is very easy to distract the driver, which in turn may make it difficult to use eco-driving habits. In urban traffic conditions it is very easy to distract the driver, which in turn may make it difficult to use eco-driving habits. Hudak and Madlenak, (2016) and Madlenak and Hudak, (2016) demonstrated the problems with concentration and perception of traffic signs in road traffic. Another research in the field of distracting drivers from proper track driving was presented by Tarkowski and Rybicka, (2020). Using eco-driving is especially difficult at the very beginning of changing the driving style, when we are at the early learning stage.

Summing up, it can be concluded that the greatest benefits of using the eco-driving style are visible in the lower number of brake applications and vehicle stops, which may result from a better analysis of the driving situation by the driver. In addition, it was noted a better flow of traffic in relation to the normal driving style.

\section{CONCLUSIONS}

This paper presents chosen results of research in the field of eco-driving a passenger car in the urban traffic. It has been shown that applicability of the eco-driving technique in urban traffic conditions in socalled routine route from work to home. The analysis of research results indicate there are no differences in parameters such as travel time and average vehicle speed, depending on the driving technique used.

There was a significant reduction in the number of brakes by approx. 35\%, during eco-driving style compared to normal driving style.

There were also differences in the number of stops up to $0 \mathrm{~km} / \mathrm{h}$, these values are smaller for the ecodriving style. Basically, these differences occur in half of the cases during road tests.

Summing up, it can be concluded that economical driving in urban traffic has great potential and it is worth using the eco-driving style in everyday commuting to work or school. Unfortunately, there are factors that influence eco-driving habits and it's very easy to distract and revert to old habits.

\section{References}

Alam, M.S. and McNabola, A. 2014. A critical review and assessment of Eco-Driving policy \& technology: benefits \& limitations. Transport Policy, 35, pp. 42-49. https://doi.org/10.1016/j.tranpol.2014.05.016 
Backalic, S., Jovanovic, D., Backalic, T., Matovic, B. and Pljakic, M. 2019. The application of reliability reallocation model in traffic safety analysis on rural roads. Transport Problems, 14(1), pp. 115-125. DOI: 10.21307/tp.2019.14.1.11

Barkenbus, J.N. 2010. Eco-driving: An overlooked climate change initiative. Energy Policy, 38, pp. 762-769.

Blatnický, M., Dižo, J., Barta, D. and Droździel, P. 2020. FEM analysis of main parts of a manipulator for mounting a compressor to a car equipped with a pneumatic suspension system. Diagnostyka, 21(2), pp. 87-94.

Borawski, A., Szpica, D., Mieczkowski, G., Borawska, E., Awad, M.M., Shalaby, R.M. and Sallah, M. 2020. Theoretical analysis of the motorcycle front brake heating process during high initial speed emergency braking. Journal of Applied and Computational Mechanics, 6, pp. 1431-1437. DOI: 10.22055/JACM.2020.35533.2679

Bujański, K. 2000. Daewoo Lanos. WKiŁ, Warszawa.

Caban, J., Vrábel, J., Šarkan, B. and Ignaciuk, P. 2019. About eco-driving, genesis, challenges and benefits, application possibilities. Transportation Research Procedia, 40, pp. 1281-1288. https://doi.org/10.1016/j.trpro.2019.07.178

Caulfield, B., Brazil, W., Fitzgerald, K.N. and Morton, C. 2014. Measuring the success of reducing emissions using an on-board eco-driving feedback tool. Transportation Research Part D, 32, pp. 253-262. https://doi.org/10.1016/j.trd.2014.08.011

Cernicky, L. and Kalasova, A. 2015. The application of telematic technologies in Slovakia - the possibility of improving road safety in the Slovak Republic. Scientific Journal of Silesian University of Technology-Series Transport, 86, pp. 5-11.

Delhomme, P., Cristea, M. and Francoise, P. 2013. Self-reported frequency and perceived difficulty of adopting eco-friendly driving behaviour according to gender, age, and environmental concern. Transportation Research Part D, 20, pp. 55-58. DOI: 10.1016/j.trd.2013.02.002

Haider, R., Yasar, A. and Tabinda, A.B. 2017. Urban emission patterns at a semi-arid site in Lahore, Pakistan. Polish Journal of Environmental Study, 26(1), pp. 59-68. https://doi.org/10.15244/pjoes/64284

Ho, S.H., Wong, Y.D. and Chang, V.W.C. 2015. What can eco-driving do for sustainable road transport? Perspectives from a city (Singapore) eco-driving programme. Sustainable Cities and Society, 14, pp. 82-88. https://doi.org/10.1016/j.scs.2014.08.002

\section{http://www.dojazd.org/wyznaczanie-trasy}

Hudak, M. and Madlenak, R. 2016. The research of driver's gaze at the traffic signs. CBU International Conference on Innovations in Science and Education, Prague, Czech Republic, Mar. 23-25, 2016, CBU International Conference Proceedings, Hajek P., Sahota T., Jones M.A., (Ed.), pp. 896-899. DOI: 10.12955/cbup.v4.870

Kalašová, A., Cernicky, L. and Kupculjakova, J. 2014. The impact of public transport priority on the traffic in the chosen part of the city of Zilina. Transport Problems, 9(2), pp. 19-26.

Kalašová, A., Skřrivánek Kubíková, S., Čulík, K. and Palúch, J. 2020. Comparison of traffic flow characteristics of signal controlled intersection and turbo roundabout. The Archives of Automotive Engineering Archiwum Motoryzacji, 88(2), pp. 19-36. DOI: 10.14669/AM.VOL88.ART2.

Konečný, V., Gnap, J., Settey, T., Petro, F., Skrúcaný, T. and Figlus, T. 2020. Environmental sustainability of the vehicle fleet change in public city transport of selected city in central Europe. Energies, 13(15), 3869. https://doi.org/10.3390/en13153869 
Kurganov, V., Gryaznov, M., Davydov, K. and Polyakova, L. 2020. Increased efficiency and reliability of maintenance of mass passenger flow with the regular route network of city transport. Scientific Journal of Silesian University of Technology. Series Transport, 108, pp. 107-119. https://doi.org/10.20858/sjsutst.2020.108.10

Larsson, H. and Ericsson, E. 2009. The effects of an acceleration advisory tool in vehicles for reduced fuel consumption and emissions. Transportation Research Part D: Transport and Environment, 14(2), pp. 141146.

Macioszek, E. and Kurek, A. 2019. A case study analysis of roundabouts entry capacity localised on one of the main road in Sosnowiec city (Poland). Scientific Journal of Silesian University of Technology. Series Transport, 105, pp. 139-156. https://doi.org/10.20858/sjsutst.2019.105.12

Madlenak, R. and Hudak, M., 2016. The research of visual pollution of road infrastructure in Slovakia. 16th International Conference on Transport Systems Telematics, Katowice Ustron, Poland, Mar. 16-19, 2016, Challenge of Transport Telematics, Mikulski J., (Ed.), Communications in Computer and Information Science, 640, pp. 415-425. https://doi.org/10.1007/978-3-319-49646-7_35

Mensing, F., Bideaux, E., Trigui, R., Ribet, J. and Jeanneret, B. 2014. Eco-driving: An economic or ecologic driving style? Transportation Research Part C, 38, 110-121. https://doi.org/10.1016/j.trc.2013.10.013

Nocera, S. and Cavallaro, F. 2011. Policy effectiveness for containing $\mathrm{CO}_{2}$ emissions in transportation. Procedia - Social and Behavioral Sciences, 20, pp. 703-713. https://doi.org/10.1016/j.sbspro.2011.08.078

Ondruš, J., Vrábel, J. and Kolla, E. 2018. The influence of the vehicle weight on the selected vehicle braking characteristics. Transport Means - Proceedings of the International Conference, pp. 384-390.

Orynycz, O., Tucki, K., Wasiak, A., Sobótka, R. and Gola, A. 2020. Evaluation of the brake's performance dependence upon technical condition of car tires as a factor of road safety management. Energies, 13(1), 9. https://doi.org/10.3390/en13010009

Pancik, J., Drgona, P. and Paskala, M. 2020. Functional safety for developing of mechatronic systems electric parking brake case study. Communications Scientific Letters of the University of Zilina, 22(4), pp. 134-143. https://doi.org/10.26552/com.C.2020.4.134-143

Piekarski, W., Stoma, M., Dudziak, A., Andrejko, D. and Ślaska-Grzywna, B. 2016. How location shapes environmental awareness among inhabitants of Eastern Poland - an empirical study. Polish Journal of Environmental Studies, 25(2), pp. 733-740. https://doi.org/10.15244/pjoes/60722

Rouzikhah, H., King, M. and Rakotonirainy, A. 2013. Examining the effects of an eco-driving message on driver distraction. Accident Analysis and Prevention, 50, pp. 975-983. https://doi.org/10.1016/j.aap.2012.07.024

Rymarz, J., Niewczas, A. and Krzyżak, A. 2016. Comparison of operational availability of public city buses by analysis of variance. Eksploatacja i Niezawodnosc -Maintenance and Reliability, 18(3), pp. 373-378. DOI 10.17531/ein.2016.3.8

Salisu, U.O. and Oyesiku, O.O. 2020. Traffic survey analysis: implications for road transport planning in Nigeria. LOGI - Scientific Journal on Transport and Logistics, 11(2), pp. 12-22. https://doi.org/10.2478/logi-2020-0011

Sarkan, B., Semanova, S., Harantova, V., Stopka, O., Chovancova, M. and Szala, M. 2018. Vehicle fuel consumption based on the data record obtained from an engine control unit. III International Conference of Computational Methods in Engineering Sciences (CMES 18). MATEC Web of Conferences, 252, 06009.

Seibokaitė, L., Levickas, M., Markšaitytė, R., Endriulaitienė, A. and Slavinskienė J. 2019. Behaviour of BMW Drivers on Urban Roads: A Naturalistic Study. Proceedings of 23 ${ }^{\text {rd }}$ International Conference. Transport 
Means, Palanga, Lithuania, Oct 2-4 2019. Transport Means - Proceedings of the International Conference, pp. 419-422.

Sivak, M. and Schoettle, B. 2012. Eco-driving: Strategic, tactical, and operational decisions of the driver that influence vehicle fuel economy. Transport Policy, 22, 96-99. https://doi.org/10.1016/j.tranpol.2012.05.010

Skrucany, T., Harantova, V., Kendra, M. and Barta, D. 2017. Reducing energy consumption by passenger car with using of non-electrical hybrid drive technology. Advances in Science and Technology Research Journal, 11(1), pp. 166-172. https://doi.org/10.12913/22998624/66505

Skrucany, T., Stopkova, M., Stopka, O. and Milojević, S. 2020. Design of a daily-user methodology to detect fuel consumption in cars with spark ignition engine. Applied Engineering Letters, 5(3), pp. 80-86.

Skrucany, T., Vrabel, J. and Kazimir, P. 2020a. The influence of the cargo weight and its position on the braking characteristics of light commercial vehicles. Open Engineering, 10(1), pp. 154-165. https://doi.org/10.1515/eng-2020-0024

Suzdaleva, B. and Nagy, I. 2014. Data-based speed-limit-respecting eco-driving system. Transportation Research Part C, 44, pp. 253-264. https://doi.org/10.1016/j.trc.2014.04.009

Synák, F., Rievaj, V., Semanová, S. and Palúch, J. 2018. The impact of using trailers on the fuel consumption. Transport and Communications, 6(1), pp. 30-34. DOI: 10.26552/tac.C.2018.1.8.

Szumska, E., Frej, D. and Grabski, P. 2020. Analysis of the causes of vehicle accidents in Poland in 20092019. LOGI - Scientific Journal on Transport and Logistics, 11(2), pp. 76-87. https://doi.org/10.2478/logi2020-0017.

Szymanek, A. 2020. System approach in road safety studies. Communications Scientific Letters of the University of Zilina, 22(4), pp. 201-210. DOI: 10.26552/com.C.2020.4.201-210.

Tarkowski, S. and Rybicka, I. 2020. Distraction of the driver and its impact on road safety. Logi 2019 Horizons of Autonomous Mobility in Europe. Edited by: Stopkova, M., Bartuska, L., Stopka, O. Transportation Research Procedia, 44, pp. 196-203. https://doi.org/10.1016/j.trpro.2020.02.053.

Uhereketal, E., Halenka, T., Borken-Kleefeld, J., Balkanski, Y., Berntsen, T., Borrego, C., Gauss, M., Hoor, P., Juda-Rezler, K., Lelieveld, J., Melas, D., Rypdal, K. and Schmid, S. 2010. Transport impacts on atmosphere and climate: land transport. Atmospheric Environmental, 44(37), pp. 4772-4816. https://doi.org/10.1016/j.atmosenv.2010.01.002.

Waluś, K.J. and Warszczyński, J. 2019. The characteristics of mechanical damage of carcass and steel belts wires that occurred during a process of sudden tire decompression on the example of road incident. $23^{r d}$ International Scientific Conference on Transport Means 2019, Palanga, Lithuania, Oct 2-4 2019. Transport Means - Proceedings of the International Conference, pp. 907-910.

Vrabel, J., Sarkan, B. and Vashisth, A. 2020. Change of driver's reaction time depending on the amount of alcohol consumed by the driver - the case study. The Archives of Automotive Engineering - Archiwum Motoryzacji, 87(1), pp. 47-56. https://doi.org/10.14669/AM.VOL87.ART4. 